\title{
Carbon offsetting by Queensland councils: motives and benefits
}

\author{
Heather Zeppel $^{\mathrm{a}}$ \\ a Australian Centre for Sustainable Business and Development, University of \\ Southern Queensland, Australia, heather.zeppel@usq.edu.au
}

\begin{abstract}
Carbon offsetting provides one avenue for local councils to mitigate their greenhouse gas emissions. This includes voluntary offsetting of council events or activities and purchasing carbon credits to offset emissions from transport, or landfill sites exceeding 25,000tCO ${ }_{2}$-e. Offsets are 'An investment in a project that reduces greenhouse gas emissions or sequesters carbon from the atmosphere' to compensate for emissions from other activities (LGAQ 2009, p. 58). Under the Carbon Credits (Carbon Farming Initiative) Act 2011, local councils can also earn carbon credits through managing landfill emissions, or environmental plantings. This paper evaluates carbon offsetting actions and motives by Queensland councils from a 2012 quantitative and qualitative survey sent to all 73 councils. Some 32 councils completed the survey with a response rate of 51\% (excluding Aboriginal shires). Seventeen Queensland councils stated that offsetting was neither necessary nor a priority due to their small size, or were unsure about offset guidelines. However, five city councils and two coastal regional councils were partially offsetting emissions mainly from vehicle fuel and electricity, or community events. Councils with a climate change strategy aiming to be carbon neutral (i.e. Cairns, Gold Coast, Redland, Sunshine Coast) were most likely to offset. The preferred offset action by councils was tree planting on council land, or in partnership with conservation groups or offset companies (Ecofund Queensland, Greening Australia, \& Greenfleet). Four councils wanted to sell/earn carbon credits, or support local landholders. The key motives for carbon offsetting included: council concern about climate impacts, supporting conservation, being climate friendly, and financially supporting offset projects. Councils preferred carbon offset methods such as tree planting or renewable energy with tangible environmental and financial benefits.
\end{abstract}

\section{Introduction}

Climate change and carbon mitigation are key issues for local government (ACELG 2011; Kebe, Bellassen \& Leseur 2011; Pillora 2011; Svara et al. 2011; Storey et al. 2012, pp. 23-4; Storey \& Eckstein 2013; Clean Energy Future 2013; Hoff \& Strobel 2013; 
Iraldo \& Gasbarro 2013; Zeppel 2013; Zeppel forthcoming). Reports include advice and case studies on greenhouse gas mitigation actions for local councils, including offsetting (QLGA 2009; Storey et al. 2012, pp. 23-4). Australia is a signatory to the Kyoto Protocol, with a national target of 5\% emissions reduction on 2000 levels by 2020. Local councils are now required to report their carbon emissions over $25,000 \mathrm{tCO}_{2}$-e a year from a single facility (i.e. landfill) under the Clean Energy Act 2011. Some 40 Australian councils are now liable entities for the carbon tax from landfill emissions or gas supply (CER 2013a). The carbon price of AUD $\$ 23 \mathrm{tCO}_{2}$-e from 1 July 2012 ( $\$ 24.15 \mathrm{tCO}_{2}$-e from 1 July 2013) also impacts on council operations through the increased cost of electricity and materials (ALGA 2011; IPART 2011; LGAQ 2012). Councils are thus adopting ecoefficiency measures, and offsetting emissions, to reduce operating costs and carbon liability.

This paper evaluates carbon offsetting actions implemented by 32 Queensland local councils. As part of the broader national response to global warming, local government in Queensland faces the challenge of implementing policy, organisational and technical initiatives to mitigate its carbon emissions (LGAQ 2009; Steffen et al. 2012). This includes reporting of greenhouse gas emissions over a threshold of $25,000 \mathrm{tCO}_{2}$-e to the Clean Energy Regulator under the Clean Energy Act 2011. To date, 12 Queensland councils have been listed as liable entities by the Clean Energy Regulator: 10 larger councils from landfills (i.e. Brisbane, Gold Coast, Logan, Townsville, Gladstone, Mackay, Moreton Bay, Rockhampton, Sunshine Coast and Toowoomba) while two regional councils are liable as natural gas suppliers (i.e. Maranoa and Western Downs). In that context, this paper reviews carbon offsetting responses by Queensland local councils at the city, regional, and shire levels (Zeppel \& James-Overheu 2012a; Zeppel 2012a). It considers the varied size, capacity and motives of Queensland councils to adopt carbon offsetting. It also extends a pilot survey of Greater Adelaide councils (Zeppel 2012b) to a State-wide survey of Queensland councils.

\section{Queensland local government}

There are 73 local government areas (LGAs) in Queensland, including seven city councils, 30 regional councils, 24 shire councils, and 12 Aboriginal shire councils. These councils range in size from five of the 10 largest LGAs for Australia in the high urban growth region of South East Queensland (SEQ; i.e. Brisbane, Gold Coast, Moreton Bay, Sunshine Coast, and Logan); mid-size regional centres in coastal and inland areas; and small rural or Aboriginal shires with less than 1,000 residents. These LGAs operate under the Queensland Local Government Act 2009. The City of Brisbane Act 2010 covers Brisbane City Council as a corporation managing the largest LGA (by population) 
in Australia. There is no state-wide climate change strategy for Queensland LGAs and no renewable energy, GreenPower or other carbon mitigation targets for local government have been set by the State government. The Local Government Association of Queensland has published a Climate Change Mitigation guide (LGAQ 2009), including advice on carbon offsetting to reduce emissions. A regional carbon plan by five LGAs in Far North Queensland set a target of 50\% reduction in carbon emissions on 2007/08 levels by 2020 from council operations, and a regional offset planting policy for revegetation (FNQROC 2011). The Council of Mayors SEQ previously supported regional carbon sinks with tree planting on council land in Ipswich, Redland and Moreton Bay in 2009 for 11 SEQ councils to offset emissions (LGAQ 2009). The climate change plans of four coastal councils in Queensland have set a goal of being carbon neutral by 2020 in their operations by purchasing offsets (i.e. Brisbane [2026], Cairns, Gold Coast, and Sunshine Coast) (BCC 2008).

\section{Carbon offsetting}

Carbon offsetting provides one avenue for local councils to mitigate their greenhouse gas emissions. Council vehicle fleets are offset through Greenfleet and regional tree planting initiatives (Newman 2010). City councils purchase carbon credits to offset emissions from transport or landfill (BCC 2008). Carbon offsets are defined as 'An investment in a project that reduces greenhouse gas emissions or sequesters carbon from the atmosphere,' to compensate for emissions from other activities (LGAQ 2009, p. 58). Carbon offsets are sold in both voluntary (National Carbon Offset Standard) and compliance (Australian Carbon Credit Unit) markets. A local government carbon offset checklist recommended councils seek offset products that were accredited, independently verified, and provided other environmental benefits (Balance Carbon 2010; LGASA 2010). Carbon credits from renewable energy, forestry, and methane reduction projects are sold by accredited offset companies such as Ecofund Queensland (2013), Greenfleet (2013), Greening Australia (2013) and other carbon brokers (Low Carbon Australia 2013). Under the Carbon Credits (Carbon Farming Initiative) Act 2011, local councils can engage in Carbon Farming Initiative (CFI) projects through managing landfill emissions, by native reforestation, or savannah burning (DCCEE 2012; CER 2013b). Key offsetting issues were CFI guidelines, project approvals, and ancillary benefits (Moore 2011).

In western Sydney, the Regenesis project established 33 carbon forests compliant with the Kyoto Protocol, with 21 forests on council land and 10 on private land (Storey et al. 2012, pp. 23-4). Land owners generate income through trading Regenesis carbon offset certificates in the NSW Greenhouse Gas Reduction Scheme, National Carbon 
Offset Standard, or CFI (BCC \& LPSC 2011). However, the NSW State government has banned NSW local councils from buying carbon credits as a financial product, with a legal quandary over meeting carbon liability (AAP 2012; Benson 2012). In Victoria, the South East Councils Climate Change Alliance established the Bunyip Carbon Sink project with regional planting of native trees to offset the emissions of five councils. Member councils purchased carbon from biodiversity plantings to offset their vehicle fleets. The Northeast and Central Greenhouse Alliances in Victoria also developed tree plantings for carbon sequestration and assessed their future carbon trading potential (SECCA 2012a, SECCA 2012b). In South Australia, 10 councils assessed land areas and vegetation with potential to earn CFI carbon credits (LGASA 2012). This paper evaluates carbon offsetting actions adopted by Queensland local councils.

\section{Methodology}

The climate change mitigation survey for Queensland councils was based on carbon mitigation actions recommended in the Cities for Climate Protection (CCP) program, and a desktop review of climate change plans and carbon actions listed on Queensland council websites (Zeppel 2011b). The survey also adopted some questions from ICLEI's review of Australian (and New Zealand) councils in the CCP program (Hoff 2010), and previous climate change surveys of New South Wales local councils (DECCW 2010; LGSA 2010). These Australian surveys of local councils included a range of carbon mitigation actions relevant to Queensland councils, while local government associations have assessed carbon price impacts on selected councils (LGAQ 2012; MAV 2012). Similar surveys in the USA have evaluated carbon mitigation actions by municipalities (Svara et al. 2011), and planners (Tang et al. 2009). Sustainability officers at two large Queensland councils with climate change programs provided feedback on questions in the draft survey. A pilot climate change survey was also conducted of 14 Greater Adelaide councils in 2011 to assess their carbon mitigation and offsetting actions (Zeppel 2011b; Zeppel 2012b; Zeppel \& James-Overheu 2012b).

The Queensland council survey included 36 main questions organised in five sections: A: Your Local Council; B: Climate Change; C: Climate Change Mitigation; D: Carbon Offsetting; and E: Preparing for the Carbon Price. The survey included climate change responses, a checklist of 64 carbon mitigation actions, ranking of council motives for carbon actions, and open-ended questions on reasons for climate change actions by councils. This survey was circulated to all 73 Queensland councils, by email, post and follow-up telephone calls, during January to May 2012. A total of five (of 7) city councils (CC), 18 (of 30) regional councils (RC), eight (of 24) shire councils (SC), and 
one (of 12) Aboriginal shire councils (ASC) completed the survey. The response rates for each type or category of council in this survey were: CC (71\%), RC (60\%), SC (33\%) and ASC (8\%). Hence survey responses from city and regional councils are representative, while shire councils are under-represented in the results. Excluding the Aboriginal shire councils, the response rate for this carbon survey among all other Queensland councils (31 of 61) was 51\%. In the results, councils are referred to by type (i.e. city, regional, or shire), and geographic location (i.e. coastal or inland). The survey was mainly completed by council staff with roles related to environmental, sustainability, and climate change areas (78\%). At smaller councils, the survey was completed by the CEO or environmental health officers; and by building or engineering staff. Other council staff or councillors may have different responses to climate change and carbon issues. Comments by council respondents in the survey are included to highlight key issues in carbon management. This paper reports on survey responses to section D on carbon offsetting actions by Queensland local councils. This includes council involvement in offsetting, types of offset providers/projects supported, and council motives and benefits from offsetting.

\section{Results}

Two thirds of surveyed Queensland councils (20) assessed that climate change was an important issue for local government (5 CC, 13 of 18 RC, and 2 SC). Climate change was considered important because of the potential impacts on council infrastructure, service delivery, risk minimisation, community safety, biodiversity, and economic development. Fourteen councils (5 CC, 8 RC, and 1 SC) were previously engaged in the CCP program. Out of a total of 433 carbon reduction actions adopted by 30 Queensland councils, less than $3 \%$ of council climate initiatives related to carbon offsetting actions (11). The main opportunities identified by Queensland councils to reduce their carbon emissions were through waste management and recycling (16), managing methane from landfills (15), planting trees on council land (14), green building design (12) and renewable energy (11). Planting trees on council land for carbon offsetting was preferred by four CC, eight RC and two SC. Just three councils in SEQ (1 CC, and 2 RC) listed carbon offset markets or buying carbon credits as an opportunity to reduce emissions from council activities (e.g. landfill), with Sunshine Coast Council building a 'portfolio of offsets.' 


\section{Council participation in carbon offset program}

Seven Queensland councils were partly offsetting their carbon emissions, including five CC, the Sunshine Coast Council, and a coastal council. Townsville offset its 'community event Eco Fiesta.' Three regional councils and one shire council in western Queensland planned to start offsetting in the next 12 months. However, 18 councils indicated carbon offsetting was not necessary (11), or not a priority (7) (Table 1). Most shire councils and three inland regional councils did not consider that carbon offsetting was necessary due to their small size, smaller populations, and being below the carbon threshold. Six other regional councils and the largest shire council focused on reducing their carbon emissions rather than offsetting. Not one Queensland council offsets emissions totally, although four large coastal councils plan to be carbon neutral by 2020, i.e. Brisbane (2026), Cairns, Gold Coast, and Sunshine Coast. Brisbane City Council, with a likely carbon tax bill of $\$ 65$ million over four years, 'has offset its public transport and vehicle fleets' (Hepworth, 2012: 5), and has bought 100\% GreenPower since 2010 as Australia's largest purchaser of renewable energy. The 2012/13 budget for Brisbane Council included \$3.5 million for landfill carbon permits (Moore 2012).

Tab. 1. Carbon offsetting by Queensland councils

\begin{tabular}{lrrrrrr} 
Carbon offsetting & $\begin{array}{c}\text { Ab.Shire } \\
\text { Council }\end{array}$ & $\begin{array}{c}\text { Shire } \\
\text { Council }\end{array}$ & $\begin{array}{c}\text { Regional } \\
\text { Council }\end{array}$ & $\begin{array}{c}\text { City } \\
\text { Council }\end{array}$ & \multicolumn{1}{c}{ Total } \\
\hline No- not necessary & 1 & 6 & 4 & 0 & 11 \\
\hline No- not a priority & 0 & 1 & 6 & 0 & 7 \\
\hline Yes - partially offset & 0 & 0 & 2 & 5 & 7 \\
\hline No-next 12 months & 0 & 1 & 3 & 0 & 4 \\
\hline
\end{tabular}

\section{Council position or policy on carbon offsetting}

A few city and regional councils commented on their council's position or policy on carbon offsetting. This included offsetting as part of a carbon neutral policy (Gold Coast); an unofficial position to reduce emissions first, then to utilise mandated offsets (Logan); and some initial investment in offsets (Redland). The carbon neutral plan for the Sunshine Coast Regional Council requires offsetting of residual emissions by 2020. Cairns Regional Council also has offsetting requirements as 'Council has carbon neutrality in its carbon reduction goal for 2020.' Other coastal councils offset events, or wanted to learn more about carbon credits and offset guidelines, but it was a low priority for one inland council. South Burnett Regional Council was 'willing to investigate options that can be incorporated and enhanced within existing Council operations and the possibility of working with landholders and industry to provide carbon offsets or credits.' 
It has evaluated carbon offset options (i.e. environmental plantings, native forest protection, landfill methane gas) and analysed the biosequestration potential of native forest growth in the South Burnett region (SCS 2012, pp. 47-56).

\section{Council investment in carbon offset projects}

Between 2004 and 2010, the five city councils all started investing in carbon offset projects. Two coastal regional councils began buying offsets from 2010 or 2011, while two others planned to fund offsets from 2014. One shire council in Western Queensland indicated it invested in offset projects from 2010-11 'through research'. Another 22 Queensland councils did not indicate when they would start investing in carbon offsetting as it was not considered a priority or it needed an official council position or policy on offsetting. The initial stimulus for offsetting was the Carbon Pollution Reduction Scheme (LGAQ 2009), with the eventual Clean Energy Act 2011 setting a carbon price and liable entities for emissions.

\section{Type of carbon offset project implemented or planned by council}

Mainly larger city and regional councils have implemented or planned carbon offsetting. Ten Queensland councils (5 CC, 3 RC, and 2 SC) in the survey supported carbon offsetting by planting trees on council land, and/or in partnership with organisations involved in regional tree planting (Figure 1). Just four respondents had paid for carbon credits through an Australian offset provider. These included the Gold Coast and Townsville city councils, Sunshine Coast, and Gladstone councils. Only the Sunshine Coast Regional Council had paid for carbon credits through an international offset provider. Three other larger regional councils and the Aboriginal shire had not discussed or decided on the type of carbon offset project. Only Redland and Townsville city councils had purchased renewable energy to offset council emissions. Another 16 Queensland councils (10 RC, and 6 SC) did not respond to this question on the preferred type of offset project.

\section{Types of council emissions offset}

The abatement strategy is to avoid, reduce, switch, sequester, and then offset (FNQROC 2011). The councils offsetting their emissions are mainly applying it to vehicle fuel and electricity for the council office and facilities (Table 2). Townsville City Council offsets fuel in hire vehicles used by staff. Two larger coastal councils were also offsetting their events: 'community event-Eco Fiesta' (Townsville), and one general 'Event based (air transport, electricity, fuel (car/truck)' offsetting policy. Logan City Council offset its printed materials, while at Redland City Council offsetting was 
'general i.e. total emissions offset.' There was ad hoc offsetting of airline travel by staff at Sunshine Coast Council. Mackay Regional Council had not decided on the type of emissions offsetting. Most regional and shire councils (20) did not respond on the types of emissions offset; they were all below the threshold of $25,000 \mathrm{tCO}_{2}$-e that required reporting emissions.

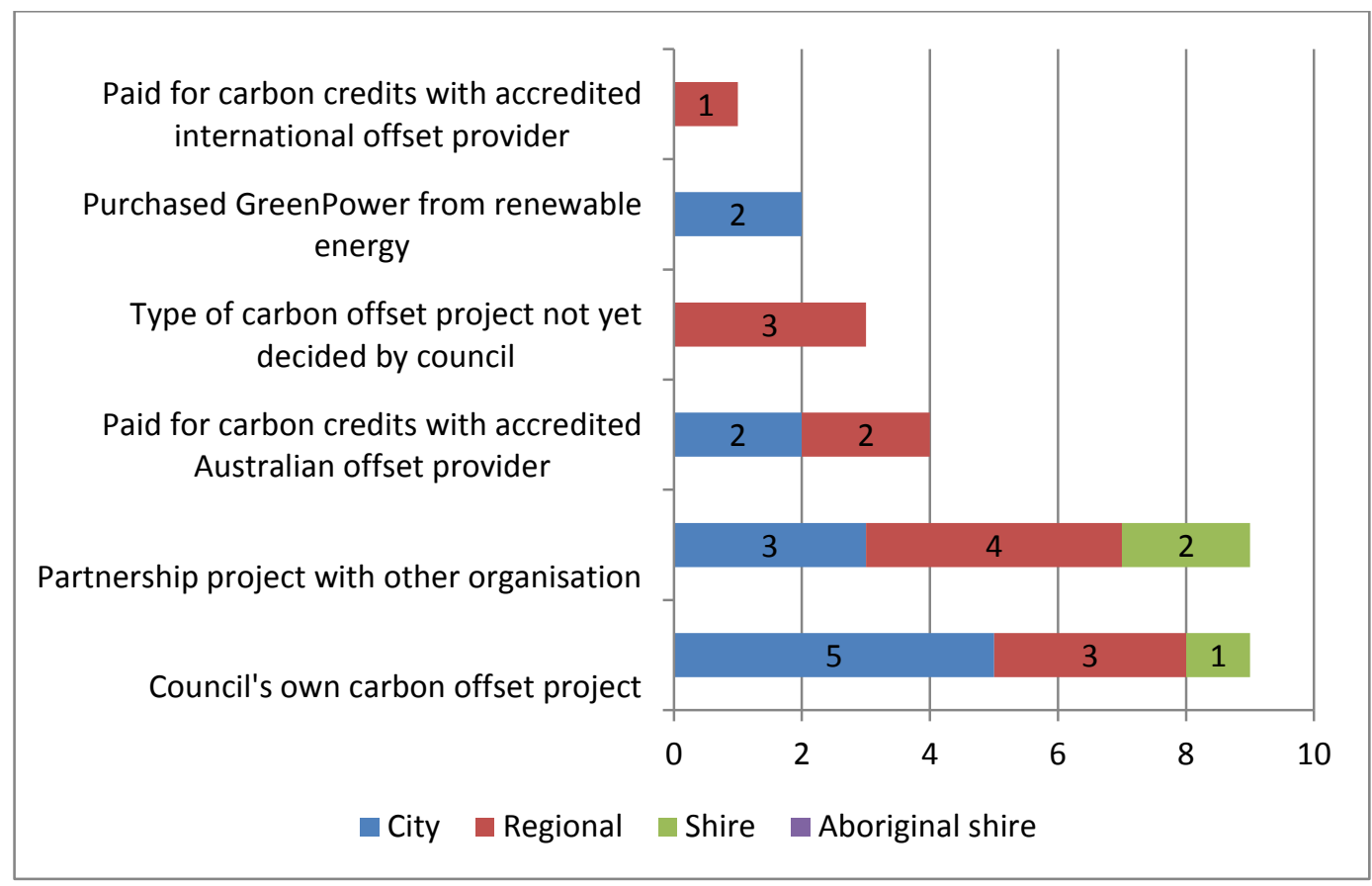

Fig. 1. Carbon offset project implemented by Queensland councils

Tab. 2. Types of emissions offset by Queensland councils

\begin{tabular}{lcccc} 
Emissions offset & $\begin{array}{c}\text { Shire } \\
\text { Council }\end{array}$ & $\begin{array}{c}\text { Regional } \\
\text { Council }\end{array}$ & $\begin{array}{c}\text { City } \\
\text { Council }\end{array}$ & Total \\
\hline Vehicle or plant fuel & 1 & 1 & 2 & 4 \\
\hline Council office electricity & 1 & 1 & 2 & 4 \\
\hline Council facilities electricity & 1 & 1 & 1 & 3 \\
\hline Other (i.e. events) & 0 & 1 & 1 & 2 \\
\hline Airline travel (council staff) & 0 & 1 & 0 & 1 \\
\hline Council printed materials & 0 & 0 & 1 & 1 \\
\hline Not yet decided & 0 & 1 & 0 & 1 \\
\hline Fuel usage (hire vehicles) & 0 & 0 & 1 & 1 \\
\hline
\end{tabular}

\section{Carbon offset method financially supported by council}

The main carbon offset methods supported by Queensland councils included energy efficiency, renewable energy and waste diversion, followed by landfill gas (Table 3). 
Two coastal regional councils supported offsetting through tree planting. Overall, 10 Queensland councils (5 CC, 3 RC, and 2 SC) previously nominated tree planting as their preferred carbon offset project - by planting trees on council land, and/or in partnership with organisations involved in regional tree planting (Figure 1). Two northern councils supported soil carbon as an offset method (Townsville and one Shire). Some Queensland councils did not separate emissions reduction from extra offsetting actions.

Tab. 3. Carbon offset methods supported by Queensland councils

\begin{tabular}{lcccc} 
Offset method & $\begin{array}{c}\text { Shire } \\
\text { Council }\end{array}$ & $\begin{array}{c}\text { Regional } \\
\text { Council }\end{array}$ & $\begin{array}{c}\text { City } \\
\text { Council }\end{array}$ & Total \\
\hline Energy efficiency & 1 & 3 & 2 & 6 \\
\hline Renewable energy & 1 & 3 & 2 & 6 \\
\hline Waste diversion & 0 & 4 & 2 & 6 \\
\hline Landfill gas & 0 & 2 & 2 & 4 \\
\hline Tree planting & 0 & 2 & 0 & 2 \\
\hline Soil carbon & 1 & 0 & 1 & 2 \\
\hline
\end{tabular}

\section{Council preference for carbon offset method}

City council preferences for carbon offset methods were driven by cost, best return for investment, supporting local famers (soil carbon), and constraints on land, or limited scope for some offset methods (tree planting). Regional councils also preferred offset methods that generated credits, aligned with council business, involved tree planting by community organisations, and provided tangible results in a short payback period. Mackay Regional Council reported they wanted 'to learn more about the options available to local government for tree planting and soil carbon, there is just too much uncertainty at present.' Sunshine Coast Regional Council preferred offset methods with the 'potential to generate own credits, costs' (i.e. landfill gas, tree planting, waste diversion). One shire council sought 'longer term financial opportunities' from carbon offset methods. Redland City Council noted they had 'limited scope for landfill gas and energy efficiency remains, [and] we have limited land for tree planting so that leaves...two’ [renewable energy, waste diversion].

\section{Carbon offset provider supported by council}

Ten Queensland councils with offset programs supported Ecofund Queensland (4), Greening Australia (2), vehicle offsets with Greenfleet (2), Climate Friendly (1), and Conservation Volunteers Australia (1) - these focused on tree planting. Other offset 
providers preferred by councils were 'local accredited carbon offset companies' (Townsville City Council), or 'mixed service providers for our portfolio of offsets' (Sunshine Coast Council). Larger councils preferred carbon offsetting by tree planting through recognised providers such as Ecofund Queensland and Conservation Volunteers Australia (CVA), based on their 'local capacity and knowledge' to implement offsets, or given that they had been 'previously used for other projects' (CVA). Gold Coast City Council noted 'This [Ecofund] was set up by the State Government for Queensland departments and LGAs.' Another 10 councils were either not sure or had not yet decided which carbon offset provider to support (2 CC, 5 RC, 2 SC, and 1 ASC). Redland City Council noted that 'Some councils own large lots or have sizable rural areas, offering carbon sink opportunities'. Some respondents were aware that they could earn carbon credits from offset projects, or income by leasing land to tree planting offset providers. Only a few larger councils listed carbon offsetting as a mitigation action in a climate change plan.

\section{Council motives for implementing a carbon offset program}

Survey responses indicated that the main motives for Queensland councils to implement carbon offsetting (Table 4) were: (1) council concern about climate change impacts, (2) supporting biodiversity/conservation; (3) promoting council as climate friendly; and (4) financially supporting tree planting or renewable energy. Secondary motives for councils to implement offsetting were earning carbon credits, meeting emission reduction targets (Redland City), and reaching carbon neutrality (Sunshine Coast Council). For larger coastal councils (i.e. Cairns, Redland, Sunshine Coast), carbon reduction targets and/or the goal of carbon neutrality are key drivers for carbon offsetting. However, 18 Queensland councils did not consider carbon offsetting a priority or a necessity.

Tab. 4. Motives to implement carbon offsetting

\begin{tabular}{lcrr}
\hline Motive to Implement Carbon Offsetting & Number & Rank \\
\hline Major reasons to implement offsetting (> 5 responses) & 10 & 2.2 \\
\hline Concern about environmental impacts of climate change & 8 & 2.3 \\
\hline The 'right thing to do' for the environment (i.e. conservation) & 8 & 2.8 \\
\hline Promote Council as a climate friendly business enterprise & 8 & 2.8 \\
\hline Financially support tree planting or renewable energy projects & & \\
\hline Minor reasons to implement offsetting (< 5 responses) & 4 & 1.2 \\
\hline Generate income or earn carbon credits from carbon farming initiative & 2 & 1.5 \\
\hline Other: 'meet emission reduction targets' 'reach carbon neutrality' & & \\
\hline
\end{tabular}




\section{Main benefits to council of investing in a carbon offset project}

Five councils wanted to earn carbon credits through landfill emission avoidance projects (Table 5). This included one city council and four larger regional councils. A few councils wanted to sell carbon credits, partner with local businesses for offset projects on council land, or support landholders to establish offset projects on private land (four each). Half of the surveyed Queensland councils (17) were unsure about carbon offsetting guidelines for councils in the Carbon Credits (Carbon Farming Initiative) Act 2011. Seven councils (4 RC, and 3 CC) did not respond, highlighting the uncertainty about carbon offsetting.

Tab. 5. Perceived benefits of investing in carbon offsetting

\begin{tabular}{lrrrrr} 
Carbon offset benefits & $\begin{array}{c}\text { Shire } \\
\text { Council }\end{array}$ & $\begin{array}{c}\text { Regional } \\
\text { Council }\end{array}$ & $\begin{array}{c}\text { City } \\
\text { Council }\end{array}$ & Total \\
\hline Unsure about guidelines & 6 & 9 & 2 & 17 \\
\hline Earn landfill carbon credits & 0 & 4 & 1 & 5 \\
\hline Sell carbon credits & 1 & 3 & 0 & 4 \\
\hline Support landholders & 1 & 2 & 1 & 4 \\
\hline Partner with local businesses & 1 & 2 & 1 & 4 \\
\hline
\end{tabular}

\section{Recommendations for policy and practice}

This Queensland study found five city councils and two coastal regional councils were offsetting emissions from vehicle fuel and electricity, or community events. Councils with a climate change strategy or aiming to be carbon neutral (i.e. Cairns, Gold Coast, Redland, Sunshine Coast) were most likely to offset. The preferred offset action by councils was tree planting on council land or in partnership with conservation groups. Only a few councils bought carbon credits. Councils mainly preferred tree planting as a carbon offset method due to ancillary environmental and community benefits. Potential council benefits from offsetting related to earning or selling carbon credits, partnering with local businesses, or supporting private landholders. Many types of council remained unsure about carbon offset guidelines. Other barriers included the lack of a council policy on offsetting, limited land for tree planting, offsetting not aligned with council business, and the need to provide tangible environmental or financial benefits to councils. Key recommendations include councils developing a policy on offsetting for specific activities (e.g. vehicle fleet, electricity, events), and partnerships with conservation groups or landholders for tree planting projects with biodiversity benefits (DERM 2011). Offsetting could also be required for council approval of events, or in 
contracts for the supply of goods and services. Council planning schemes could direct offsets from regional tree planting to priority areas for revegetation (Newman 2010). Local councils also need training in carbon farming projects and approvals (Moore 2011).

Local councils are voluntarily offsetting emissions through regional tree planting projects. These carbon sequestration sites involve partnerships between urban and rural councils (South East Victoria, SEQ), and between councils and private landholders (Regenesis, NSW). Councils need to collaborate with regional natural resource management groups on carbon planting projects (DSEWPC 2013). The high domestic carbon price ( $\$ 24 / \mathrm{tCO}_{2}$-e versus $\$ 6 / \mathrm{tCO}_{2}$-e in the European Union) has also led to declining investment in tree planting as an Australian offset method. A limiting factor for environmental plantings of native species is the 100-year permanency rule. Registered CFI offset projects by local councils include landfill gas capture and combustion (Brisbane City, Qld; Byron Shire, NSW) and diversion of legacy waste (Southern Metropolitan Regional Council, WA). Councils mainly focus on eco-efficiency and GreenPower, with offsetting as a last option. Few councils purchase carbon credits but liable entities will need to offset landfill emissions. Councils remain cautious about offsetting due to the uncertainty over the Clean Energy Act and carbon price after the federal election in September 2013.

\section{Conclusions}

Voluntary offsetting of council vehicles, events or electricity reduces carbon emissions. To date, council opportunities for voluntary offsetting include regional tree planting projects. These provide ancillary environmental benefits for biodiversity, conservation and amenity. Partnerships between councils and conservation groups support these offset tree plantings. Barriers to offsetting by local government include the lack of a council policy on offsetting, uncertainty about CFI guidelines, offset rules, land availability, and limited offset options. In Queensland, seven councils offset emissions from events, vehicles and electricity, while key motives for offsetting were climate concerns and supporting conservation. Over half of councils remain unsure about offset guidelines, or it was not seen as a priority or a necessity. The cost and uncertainty around Federal carbon offset legislation limits council involvement. Councils with a climate change strategy/carbon neutral goal were most likely to offset, while preferred carbon offsets are tree planting or renewable energy with tangible co-benefits. 


\section{Acknowledgements}

This research was funded by Local Government Infrastructure Services, a joint initiative of Queensland Treasury Corporation and the Local Government Association of Queensland. The author thanks the sustainability officers and other staff at Queensland councils that completed this survey.

Any errors or omissions are inadvertent and the sole responsibility of the author.

\section{References}

Australian Associated Press (AAP) 2012, NSW councils barred from carbon trade, news.com.au, viewed 3 May 2013, <http://www.news.com.au/breaking-news/ national/nsw-councils-barred-from-carbon-trade/story-e6frfku9-1226471531433>.

Australian Centre of Excellence for Local Government (ACELG) 2011, Local government climate change roundtable, ACELG, viewed 11 September 2013, $<$ http://www.acelg.org.au/news-detail.php?id=147> .

Australian Local Government Association (ALGA) 2011, ALGA Submission on Carbon Price Legislation Part 1 \& Part 2, viewed 23 April 2013, <http://alga.asn.au/ ?ID=6502\&Menu=47,316> .

Balance Carbon 2010, Briefing paper - Local governments and the National Carbon Offset Standard 2009, Local Government Association of South Australia, Adelaide.

Benson, S. 2012, Tax forces councils to break law - caught in the trap on carbon, The Daily Telegraph, viewed 3 May 2013, <http://www.dailytelegraph.com.au/news/ sydney-news/tax-forces-councils-to-break-law-caught-in-the-trap-on-carbon/storye6freuzi-1226472128359>.

Blacktown City Council (BCC) \& Liverpool Plains Shire Council (LPSC) 2011, The Regenesis Toolkit, Australian Carbon Traders, Castlemaine, Victoria.

Brisbane City Council (BCC) 2008, CS6 Carbon offset purchase guideline, viewed 3 May 2013, <http://www.brisbane.qld.gov.au/documents/environment/CitySmart/ carbon_offset_guideline.pdf $>$

Burton, D. 2007, Evaluating Climate Change Mitigation Strategies in South East Queensland, Research Paper 11 (Urban Research Program), Griffith University, Brisbane.

Clean Energy Future 2013, Local government, viewed 3 May 2013, <http://www. cleanenergyfuture.gov.au/local-government/>. 
Clean Energy Regulator 2013a, Liable Entities Public Information Database, viewed 16 April 2013, <http://www.cleanenergyregulator.gov.au/Carbon-Pricing-Mechanism/ Liable-Entities-Public-Information-Database/Pages/default.aspx>.

Clean Energy Regulator 2013b, Register of offsets projects, viewed 5 April 2013, $<$ http://www.cleanenergyregulator.gov.au/Carbon-Farming-Initiative/Register-of-

Offsets-Projects/Pages/default.aspx>.

Department of Climate Change and Energy Efficiency (DCCEE) 2012, Carbon Farming Initiative, viewed 23 April 2013, <http://www.climatechange.gov.au/en/government/ initiatives/carbon-farming-initiative.aspx $>$.

Department of Environment, Climate Change and Water (DECCW) 2010, Preparing for Climate Change in NSW: Local Government Responses to a Global Problem.

Department of Environment and Resource Management (DERM) 2011, Carbon Farming in Rural Queensland: Helping the Land Sector Prepare for Carbon Market Opportunities, Office of Climate Change, Brisbane.

Department of Sustainability, Environment, Water, Population and Communities (DSEWPC) 2013, Regional NRM planning for climate change fund (Stream 1), viewed 3 May 2013, <http://www.environment.gov.au/cleanenergyfuture/regionalfund/about.html>.

EcoFund Queensland 2013, Carbon advisory \& transactional services, viewed 5 April 2013, <http://www.ecofund.net.au/for-business/large-business-government-services/ carbon.html>.

Far North Queensland Regional Organisation of Councils (FNQROC) 2011, FNQROC Greenhouse Gas Inventory and Mitigation Action Plan: Managing Risk in a Carbon Economy, FNQROC, Cairns.

Greenfleet 2013, Voluntary offsets, viewed 5 April 2013, <http://www.greenfleet.com.au/ VoluntaryOffsets.aspx>.

Greening Australia 2013, Biodiverse carbon, viewed 5 April 2013, $<$ http://www.greeningaustralia.org.au/index.php?nodeId=249>.

Hepworth, A. 2012, 'Green schemes face the axe as council caught by carbon tax', The Weekend Australian, 5-6 May, p. 5.

Hoff, J. 2010, Local Climate Protection Programs in Australia and New Zealand: Results, Dilemmas and Relevance for Future Actions, CIDEA Project Report No. 1, Department of Political Science, University of Copenhagen, Denmark.

Hoff, J. \& Strobel, B.W. 2013, ‘A municipal “climate revolution”? The shaping of municipal climate change policies', The Journal of Transdisciplinary Environmental Studies, vol. 12, no. 1, pp. 3-14. 
Independent Pricing and Regulatory Tribunal of New South Wales (IPART) 2011, Effects of the Carbon Price on Local Councils, IPART, Sydney.

Iraldo, F. \& Gasbarro, F. 2013, 'How can local authorities participate in Kyoto actions?', Joint Implementation Quarterly, vol. 19, no. 1, pp. 7-8.

Kebe, A., Bellassen, V. \& Leseur, A. 2011, Voluntary Carbon Offsetting by Local Authorities: Practices and Lessons, Climate Report No. 29. CDC Climat, viewed 19 September 2013, <http://www.cdcclimat.com/IMG//pdf/11-09-30_climate_report _29_voluntary_carbon_offsetting_by_local_authorities.pdf $>$.

Local Government Association of Queensland (LGAQ) 2009, Mitigating Climate Change: An Introductory Guide for Queensland Local Government, LGAQ, Newstead, Queensland.

LGAQ 2012, Affects (sic) of the Carbon Price on Qld Councils: Summary Analysis, LGAQ, Newstead, Queensland, viewed 3 May 2013, <http://gaq.asn.au/c/document_ library/get_file?uuid=a78273ce-cc73-402d-aebe-4bcd2dbf13d0\&groupId=10136> .

Local Government Association of South Australia (LGASA) 2010, Briefing Paper Carbon Offsets and Local Government, LGASA, Adelaide, viewed 16 April 2013, $<$ http://www.lga.sa.gov.au/webdata/resources/files/LGASA_CarbonOffsetsPaper_Oct _2010.pdf $>$.

LGASA 2012, LGA Biodiversity \& Carbon Farming Initiative Pilot Project - Circular 51.4, viewed 23 April 2013, <http://www.lga.sa.gov.au/site/page.cfm?c=24950>.

Local Government Shires Association (LGSA) 2010, Local Government Needs in Responding to Climate Change in New South Wales, Australia, Local Government NSW, Sydney.

Low Carbon Australia 2013, Carbon Offset Guide Australia, viewed 5 April 2013, $<$ http://www.carbonoffsetguide.com.au/providers>.

Moore, T. 2011, Submission to Non-Kyoto Carbon Fund discussion paper, Department of Industry, Innovation, Climate Change, Science, Research and Tertiary Education, Canberra, viewed 23 April 2013, <http://www.climatechange.gov.au/sites/ climatechange/files/files/reducing-carbon/Northwes t-Carbon-Pty-Ltd-PDF.pdf>.

Moore, T. 2012, 'Blame Brisbane City Council, Swan says', Brisbane Times, 20 June, viewed 23 April 2013, <http://www.brisbanetimes.com.au/queensland/blamebrisbane-city-council-swan-says-20120620-20nek.html>.

Municipal Association Victoria (MAV) 2012, Financial Implications of Carbon Pricing on Victorian Councils, viewed 16 May 2013, <http://www.mav.asn.au/policyservices/environment/climate-change/emissions-reduction-and-mitigation/Pages/defa ult.aspx>. 
Newman, P. 2010, 'Resilient cities', in S. Cork (ed.), Resilience and Transformation:

Preparing Australia for an Uncertain Future, CSIRO, Collingwood, Victoria, pp. 8195.

Pillora, S. 2011, Australian Local Government and Climate Change, Working Paper No.

1, Australian Centre of Excellence for Local Government, University of Technology, Sydney, viewed 23 April 2013, <http://www.acelg.org.au/news-detail.php?id=133>.

South East Councils Climate Change Alliance (SECCCA) 2012a, Projects, viewed 16 April 2013, <http://www.seccca.org.au/projects/>.

SECCCA 2012b, Greenhouse alliances - responding to the challenge of climate change, viewed 16 April 2013, <http://www.seccca.org.au/news_article.asp?data_id=120>.

Steffen, W., Hughes, L., Sahajwalla, V. \& Hueston, G. 2012, The Critical Decade:

Queensland Climate Impacts and Opportunities, Climate Commission, Canberra, viewed 23 April 2013, <http://climatecommission.gov.au/wp-content/uploads/ Queensland-report_web_final-Dec.pdf $>$.

Storey, H. \& Eckstein, D. 2012, Approaches Taken by Local Councils - Transitioning and Transforming Communities and Local Economies Towards a Low Carbon Future, UTS Centre for Local Government, viewed 19 September 2013, $<$ http://www.clg.uts.edu.au/library/reports/LGMA_Report_Hazel_FINAL2.pdf>.

Storey, H., Brennan, M., Pillora, S. \& Thomas, C. 2012, Local Action for a Low Carbon Future, Australian Centre of Excellence for Local Government, University of Technology, Sydney, viewed 23 April 2013, <http://www.acelg.org.au/newsdetail.php?id=196>.

Sustainable Corporate Solutions (SCS) 2012, Regional Carbon Management Plan South Burnett Regional Council, SCS, Queensland.

Svara, J.H., Read, A. \& Moulder, E. 2011, Breaking New Ground: Promoting Environmental and Energy Programs in Local Government, IBM Centre for The Business of Government, Washington D.C.

Tang, Z., Wei, T., Quinn, C. \& Zhao, N. 2009, 'Surveying local planning directors' actions for climate change', International Journal of Climate Change Strategies and Management, vol. 4, no. 1, pp. 81-103.

Zeppel, H. 2011a, 'Climate change governance by local councils: Carbon mitigation by Greater Adelaide councils', ACELG Local Government Researchers Forum: Local Governance in Transition, Sydney, viewed 23 April 2013, $<$ http://www.acelg.org.au/news-detail.php?id=187>.

Zeppel, H. 2011b, Queensland Local Government and Climate Change: Action Plans and Resources, Australian Centre for Sustainable Business and Development, 
University of Southern Queensland, viewed 23 April 2013, <http://www.usq.edu.au/ acsbd/projects/councils>.

Zeppel, H. 2012a, 'Climate change mitigation survey of Queensland councils: Carbon footprint management', ACELG Local Government Research Showcase and Forum, Brisbane, viewed 5 April 2013, <http://gresearch.net.au/brisbane-papers-andpresenters $>$.

Zeppel, H. 2012b, 'Governing carbon mitigation and climate change within local councils: A case study of Adelaide, South Australia', Commonwealth Journal of Local Governance, vol. 10, pp. 70-85.

Zeppel, H. 2013, 'The ICLEI Cities for Climate Protection program: Local government networks for urban climate governance', in T. Cadman (ed.), Climate Change and Global Policy Regimes: Towards Institutional Legitimacy, Palgrave Macmillan, United Kingdom, pp. 217-31.

Zeppel, H. forthcoming, 'Carbon management by Queensland local councils: Citizenship for transitioning to a low carbon future', The Journal of Corporate Citizenship, vol. 49.

Zeppel, H. \& James-Overheu, C. 2012a, Climate Change Mitigation Survey of Queensland Local Councils: Final Report, Working Paper No. 5, Australian Centre for Sustainable Business and Development, University of Southern Queensland, Springfield.

Zeppel, H. \& James-Overheu, C. 2012b, 'Climate change mitigation by Greater Adelaide councils', International Journal of Organisational Behaviour, vol. 17, no. 2, pp. 29-34. 